\title{
Dirençli biliyer ve pankreatik darlıklarda tel klavuzluğunda kullanılan iğne uçlu elektrokoter kullanımının uygulanabilirliği
}

Feasibility of using wire-guided needle-knife electrocautery for refractory biliary and pancreatic strictures

Gao DJ, Hu B, Pan YM, Wang TT, Wu J, Lu R, Wang SP, Shi ZM, Huang H, Wang SZ. Gastrointest Endosc 2013;77:752-8.

Sarılığa neden olmuş ameliyat edilemeyecek durumdaki malinitelerde biliyer pankreatik darlıkların endoskopik tedavisinde stent yerleştirilmesi temel tedavidir. Yüksek dereceli bilio-pankreatik darlıklarda ise bazen stentin yerleştirilmesini sağlayacak klavuz telin darlık proksimaline geçissi pratik olarak mümkün olmayabilmektedir. Bu durum özellikle proksimal yerleşimli biliyer darlıklarda daha çok görülmektedir. Bu durum için çözümlerden biri Soehandra stent ekstraktörün darlıkların genişletilmesinde tirbuşon gibi kullanılmasıdır. Ancak tortuoz küçük çaplı kanal varlığında bu durum sorun yaratabilmektedir. Bu durumda kurtarıcı tedavi yöntemi ise precut teknik kullanılarak iğne uçlu ile kör yapılan disseksiyondur. Bu yöntemin ise anlaşıldığı gibi riskleri mevcuttur. Bu çalışmada klavuz tel üzerinden geçirilen iğne uçlu sfinkteratom ile yapilan elektrokoter disseksiyon tekniğinin semptomatik biliyer ve pankreatik darlıklarda etkinliği ve güvenilirliği araştırılmış.

Ocak-Haziran 2011 yılları arasında rezeke olamayacak malign veya benign biliyer ve pankreatik darlığı olan olgular çalışma içine dahil edilmişler. Kolanjit, sarılık, karın ağrısı ve tekrarlayan pankreatit nedenleri olan bu olgular endoskopik tedavi için çalışmaya dahil edilmişler. 7 olgu kronik panreatit, 45 olgu benign biliyer darlik (20'sinde bening biliyer darlık), 227 olguda malign biliyer darlık mevcutmuş. Teknik olarak selektif biliyer veya pankreatik kanülasyon yapıldiktan sonra 0,035 inch (Jagwire-Zebra, black and white ve taxi klavuz teller) tel ile darlık proksimaline geçiş yapılmış. Bundan sonra 6 F-8,5 F konvansiyonel kateter dilatörler ile darlık genişletilmesi uygulanmış. Eğer darlıktan 6 F dilatör geçmez ise, bir Soehendra stent çıkartıcı (7 F-8,5 F) kullanılmış. Bu yöntemle de geçiş olmayınca klavuz tel üzerinden iğne uçlu ile elektrokoterizasyon yöntemi denenmiş. Boston Scientific iğne uçlu microknife XL sfinkteratomu, 3 lümenli bir kateter olup 7 F'den 5,5 F'e inen distal ucu olan 1-7 mm iğne boyu olan bir kateterdir. Klavuz tel üzerinden iğne uçlu darlık noktasına kadar ilerletilmiş, darlık noktasında iğne 3 mm açılmış blend akım (30 monocut, 30 monokoagülasyon) ile iğne uçlu darlıktan geçinceye kadar disseksiyon yapılmış.
Ardından genişletilme yapıldıktan sonra stent yerleştirilmiş veya NB dren konmuş. 257 olguda 6 F -8,5 F ile biliyer dilatasyon başarılı olmuş. 10 hastada darlık Soehendra stent çıkartıcı ile geçilebilmiş. Iki olgu perkütan transhepatik biliyer drenajı tercih etmiş iken 10 hasta iğne uçlu sfinkteratomiye rıza göstermiş. 9/10 olguda iğne uçlu ile yapılan disseksiyon sonrası başarılı darlık genişletilmesi uygulanabilmiş. Böylece 279 hastada endoskopik başarı oranı \%95,7'den \%98,9'a çıkartılmış. Bir olguda kısa süreli hemobili olmuş, birinde hafif pankreatit, 2 olguda hiperamilazemi, bir olguda kolanjit ve bir diğer olguda ise biliyer perforasyon gerçekleşmiş. Biliyer perforasyonlu olguya oral alım kesilerek gastrointestinal dekompresyon yapılmıs, antibiyotik ve serum tedavisi parenteral verilmiş ve bu şekilde hasta toparlamış. İşlem ile ilgili bir ölüm bildirilmemiş.

\section{YORUM}

Biliyer darlıkların endoskopik tedavisi özellikle endoskopik biliyer stentleme yöntemi konvansiyonel cerrahi girişimlere özellikle hepatikojejunostomiye göre daha güvenli ve daha iyi uzun dönem sonuçlar sağlamaktadır. Ayrıca, hepatikojejunostomi sonrası \%12-45 oranında nüksler olabilmektedir (Frattoroli FM, et al. J Am Coll Surg 1996). Ancak, endoskopik stent yerleştirilmesi olguların \%4-9'unda başarısız olabilmekte, bunun yanında kolanjit gibi risklere neden olabilmektedir (Sohendra N, et al. World J Surg 1992). Endoskopik tedavinin başarısızlığının alternatif yaklaşımları perkütan transhepatik girişim veya cerrahi olmaktadır. Cerrahinin morbidite ve mortalitesi varken, perkütan girişimler yaşam kalitesini bozmakta, normal enterohepatik dolaşıma engel olmaktadır. Endoskopik ultrasonografi (EUS) klavuzluğunda yapılan biliyer girişimler ise \%20-50 oranlarında yan etkiler ile sonuçlanabilmektedir (Ang TL, et al. JOP 2007). Asit, koagülapati veya sadece sağ IHYS geniş ise EUS klavuzluğunda yapılacak transgastrik ve transduodenal girişimler kontraendike olmaktadır. Malign biliyer darlıklarda endobiliyer radyofrekans (RF) ablasyon ile pasaj rahatlatıldıktan sonra metal stent konarak darlık palyasyonu yapılabilmektedir. Ancak,
Üstündağ Y, Parlak E, et al. Feasibility of using wire-guided needle-knife electrocautery for refractory biliary and pancreatic strictures. Endoscopy Gastrointestinal 2013;21:58-9.
İletişim:Yücel ÜSTÜNDAĞ Bülent Ecevit Üniversitesi Tıp Fakültesi İç Hastalıkları Anabilim Dalı, Gastroenteroloji Bilim Dalı Zonguldak, Türkiye $\bullet$ E-posta: yucelustundag@yahoo.com.tr Gelis Tarihi: 24.06.2013 Kabul Tarihi: 24.06.2013 
RF ablasyon kateter çapı 8 F dir (2,6 mm) ve künt uçludur ki yüksek dereceli biliyer darlıklarda darlıktan geçmesi pek mümkün değildir. Diğer yandan Sohendra stent ekstraktörler de başarısız olabilmektedir. Bir diğer yöntem ise Italya'dan Costamagna grubunun tariflediği yöntemdir; önce darlık proksimaline geçecek şekilde klavuz tel yerleştirilir. Ardından bu tel NB dren gibi buruna 24 saat sabitlenir. Duodenal peristaltizm klavuz teli orda genişletici bir buji haline getirir ve 24 saat sonra tekrarlanan endoskopik retrograd kolanjiopankreatografi ile klavuz tel üzerinden genişletici bujiler ile stent konabilir.

Bu çalışmada 10 olgunun 9'unda iğne uçlu ile kör olarak darlık içinden yapılan disseksiyon sonrası biliyer darlığın açılması, ardından endoskopik biliyer dilatasyon ve stentleme ile luminal pasajın sağlanmasının mümkün olduğunu görmekteyiz. Günlük pratiğimizde bu darlık olgularında dilatasyon için çoğunlukla Sohendra stent ekstraktörü tirbüşon gibi kullanarak darlık alanı genişletilir. Ama biliyoruz ki özellikle annülar-konsantrik darlığa neden olan dens stromalı kolanjiokarsinom olgularında bu yöntem de başarısız olabilmektedir. Benin biliyer veya pankreatik darlıklarda hipokseminin neden olduğu zengin fibrotik doku kanal duvar genişliğinde artışa neden olur. İşte bu patolojik görünümün varlığı bu çalışmanın düşünsel temelini oluşturmaktadır. Yani böyle bir fibrotik dokunun disseksiyonu etkin ve güvenilir gözükmektedir. Bu düşüncenin doğru olduğunu, bu yayında 10 hastanın 9'unda endoskopik disseksiyonla pasaj sağlanabilmesinde görmekteyiz. Burada yazarlar blend akım kullanarak disseksiyon yapmışlar. Böylece hem kanama kontrolü sağlanmış, hem de doku disseksiyonu gerçekleştirilmiş. Bu arada floroskopi ile safra kanalı, retroperiton ve böbrek çevresinde serbest hava varlığı araştırılmış. Yazarlar, biliyer perforasyon olgusunda, iğnenin kateterden 7 mm kadar çıktığı ve disseksiyon aksının kanal aksından farklı yöne kayması nedeni ile perforasyon olduğunu belirtmekdirler. Iğnenin kendi üzerine 180 derece katlanması ile belki bu komplikasyonun engellenebileceği ifade edilmekle beraber, bu durumda da asimetrik disseksiyon ve perforasyon riskinin olabileceği unutulmamalıdır. Alternatif olarak 6 F sistotom ile bu yöntemin denenebileceği düşünülebilir. Diğer bir konu da, komplikasyonların darlığın uzunluğu ile korelasyon göstermesidir. Örneğin, işlem sonrası olan biliyer kanama $5 \mathrm{~cm}$ uzunluğunda darlık segmenti bulunan post-transplant biliyer darlık olgusunda gerçekleşmiştir. Önemli noktalardan biri de, bu hasta grubunda pankreatik darlık olan 1 hasta mevcuttur. Çalışmanın başlı̆̆ı refrakter biliyer ve pankreatik darlıklar olarak geçmekle beraber sadece bir hastada elde olunan bulgular ile sonuçlar çıkarmak oldukça zordur. Yani bu çalışmanın en önemli eksikliği, hasta sayısının az olmasıdır. Daha geniş hasta gruplarında işlem ile ilişkili yan etkilerin daha iyi tariflenmesi ve optimal endikasyonlarının daha iyi belirlenmesi gerekmektedir.

\section{Yücel ÜSTÜNDAĞ}

Bülent Ecevit Üniversitesi Tıp Fakültesi Iç Hastalıklan Anabilim Dalı, Gastroenteroloji Bilim Dal, Zonguldak

Erkan PARLAK

Yüksek Ihtisas Hastanesi Gastroenteroloji Kliniği, Ankara 